\title{
Expression Profile of Hepatic Metallothionein-I and ATP7B, and Brain Metallothionein-III and Acetyl cholinesterase Genes in Wistar Rat Model for Non-Wilsonian Brain Copper Toxicosis
}

\author{
Pal A and Prasad R
}

\section{Department of Biochemistry, PGIMER, Chandigarh, India}

*Corresponding author: Prasad R, Department of Biochemistry, PGIMER, Chandigarh, India, Fax: +91172-2744401/2745078, Tel: +91-172-2755178, E-mail: fateh1977@yahoo.com

Citation: Pal A, Prasad R (2015) Expression Profile of Hepatic Metallothionein-I and ATP7B, and Brain Metallothionein-III and Acetyl cholinesterase Genes in Wistar Rat Model for Non-Wilsonian Brain Copper Toxicosis. J Neurol Neurol Disord 2(1): 102 . doi: 10.15744/2454-4981.2.102

Received Date: February 06, 2015 Accepted Date: March 23, 2015 Published Date: March 27, 2015

\begin{abstract}
Cognitive waning due to chronic copper $(\mathrm{Cu})$ intoxication in animal models is increasingly being reported; notwithstanding, information regarding molecular basis of $\mathrm{Cu}$ accumulation and neurobehavioral impairments remains fragmentary. Previously, we have shown first in vivo evidence of spatial memory impairments along with astrocytes swelling (Alzheimer type II cells) and astrogliosis (increase in number of astrocytes), $\mathrm{Cu}$ deposition in the choroid plexus and degenerated neurons with significant increase in the hippocampus $\mathrm{Cu}$ content in $\mathrm{Cu}$-intoxicated Wistar rats. In continuation with our previous study, the aim of this study was to investigate the effects of intraperitoneally injected $\mathrm{Cu}$ lactate $(0.15 \mathrm{mg} \mathrm{Cu} / 100 \mathrm{~g}$ body weight) daily for 90 days on metallothionein-I (MT-I), ATP7B, MT-III and acetylcholinesterase (AChE) gene expression by reverse transcription polymerase chain reaction. Cu-intoxicated group showed significantly increased expression of hepatic MT-I gene compared to control group. However, hepatic ATP7B mRNA levels in Cuintoxicated group were comparable with that of control group. Similarly, MT-III and AChE gene expression in the brain were not significantly altered by chronic $\mathrm{Cu}$-intoxication. In conclusion, the current study demonstrates that chronic Cu toxicity causes increase in hepatic MT-I mRNA levels in male Wistar rats.
\end{abstract}

Keywords: Copper intoxication; Metallothionein; Cognition; Neuro degeneration

\section{Introduction}

Copper $\left({ }_{29} \mathrm{Cu}^{63.5}\right)$ is the third-most abundant transition metal in the brain with highest concentration found in the liver. Owing to its redox activity, $\mathrm{Cu}$ serves as a cofactor for key metabolic enzymes that mediate various cellular processes, including neurotransmitter biosynthesis (dopamine $\beta$ hydroxylase), mitochondrial energy generation (cytochrome $c$ oxidase), free radical detoxification $(\mathrm{Cu} / \mathrm{Zn}$ superoxide dismutase) and iron homeostasis (ceruloplasmin) $[1,2]$. There is uneven distribution of Cu in different regions of the brain with variations reported in different age groups [3], and species to species [4]. Average neural $\mathrm{Cu}$ concentrations are the order of $0.1 \mathrm{mM}[1]$.

Brain is particularly sensitive to free radical damage and oxidative stress because of the high levels of polyunsaturated lipids that are component of neuronal cell membranes [5]. The abundance of $\mathrm{Cu}$ in the brain and its strong redox activity necessitates tight control over $\mathrm{Cu}$ homeostasis to evade oxidative injury to the central nervous system (CNS) by uncontrolled Cu-elicited HaberWeiss and Fenton type reactions. Cells have therefore developed various protection mechanisms in event of drastic increase in $\mathrm{Cu}$ concentration. The incorporation of $\mathrm{Cu}$ into metallothionein (MT) is an example of cells defense mechanisms to protect cell structure from $\mathrm{Cu}$ toxicity and to prevent oxidative damage [6]. Four types of closely related MT genes (MT I-IV) are present in rodents [7,8]. While MT-I and MT-II are ubiquitously expressed, MT-III and MT-IV are primarily confined in the CNS and stratified squamous epithelia, respectively [9].

In recent years an overwhelming number of studies have shown relevance of MT in neurophysiological and neuromodulatory functions by documenting very high levels of brain-specific isoform MT-III in the CNS [10]. Haywood et al. have shown strong immunoreactivity for MT in the astrocytes of the North Ronaldsay sheep, an animal model for idiopathic Cu toxicosis (ICT) [11]. Increased expression of hepatic MT-I gene has been documented in toxic milk mice, an animal model of Wilson's disease (WD) [12]. It is well established that point mutation or a partial deletion in ATP7B gene, which encodes Cu transporting P-type ATPase, causes WD resulting in $\mathrm{Cu}$ accumulation in the liver, brain and cornea [13]. In addition, there is mounting proof that $\mathrm{Cu}$ dyshomeostasis in Alzheimer disease (AD) patients leads to oxidative stress and neuro degeneration [14] subsequently resulting in memory deficits. Central cholinergic system plays a significant role in learning, memory, and cognition in both animals and humans [15]. Notably, acetylcholinesterase (AChE) has been shown to be affected by $\mathrm{Cu}[16]$. 
Earlier, we have reported a Wistar rat model for non-Wilsonian brain Cu toxicosis; documenting first in vivo evidence of memory deficits in conjunction with $\mathrm{Cu}$ deposition in the choroid plexus, decreased serum AChE activity, astrocytes swelling (Alzheimer type II cells) accompanied by astrogliosis (increase in number of astrocytes), degenerated neurons in cerebral cortex, and augmented levels of $\mathrm{Cu}$ in the hippocampus of chronically $\mathrm{Cu}$-intoxicated male Wistar rats. In addition, liver sections of chronic $\mathrm{Cu}$-intoxicated rats showed grade $1 \mathrm{Cu}$-associated protein and grade $4 \mathrm{Cu}$ depositions by the Shikata's orcein stain and Rhodanine stain, respectively [17]. Importantly, MT has been confirmed as the biochemical counterpart of orcein positive material [18].

The widespread distribution of $\mathrm{Cu}$ prerequisite for normal CNS functioning, coupled with many links between Cu dyshomeostasis and neurodegenerative diseases, have impelled curiosity in studying MT, ATP7B and AChE gene expression in chronic Cuintoxicated rats. In this study, we have reported the molecular basis of $\mathrm{Cu}$ accumulation in brain and liver with relation to development of neurodegeneration and neurobehavioral impairments in Wistar rat model for non-Wilsonian brain Cu toxicosis.

\section{Materials and Methods}

\section{Chemicals}

Copper chloride, agarose, chloroform, isopropyl alcohol (Merck) and lactic acid (Qualigens fine chemicals) were purchased. All the other reagents and chemicals used in this study were of analytical grade.

\section{Animals and Experimental design}

Male Wistar rats (starting at 3 weeks of age) in the weight range of 60-80 g were procured from the institute animal house, PGIMER, Chandigarh, India. All the rats were housed in the polypropylene cages (one animal per cage), kept in well ventilated rooms maintained at $22 \pm 2{ }^{\circ} \mathrm{C}$. The rats were fed standard rat chow and water ad libitum. Institutional Animal Ethical Committee (IAEC-161) consent was taken and IAEC guidelines were strictly followed for all the animal experimentation. Two groups of male Wistar rats, each consisting of eight animals were used as follows:

Control group: Intra peritoneal (i.p.) injection of isotonic sodium chloride solution daily for the period of 90 days. For ethical reasons, group receiving sodium lactate solution was not kept as it has been reported previously that it does not alter any vital biochemical parameters and $\mathrm{Cu}$ levels in various tissues in Wistar rats $[17,19]$.

Cu-intoxication group: Intra peritoneal (i.p.) injection of $\mathrm{Cu}$ lactate solution $(0.15 \mathrm{mg} \mathrm{Cu} / 100 \mathrm{~g}$. B.W. $)$ daily for the period of 90 days [17].

\section{Collection and preservation of tissue samples}

All the animals were sacrificed at the end of $99^{\text {th }}$ day of the study under ether anesthesia after completion of neurobehavioral studies [17], and brain and liver were dissected out. Tissues were cut with clean stainless steel scalpel blades. For expression studies, the liver and brain tissues were immediately transferred to autoclaved tubes containing Trizol ${ }^{\oplus}$ reagent. All the samples were stored at $-80^{\circ} \mathrm{C}$ till further processing.

\section{Expression of MT-I, ATP7B, MT-III and AChE by semi-quantitative reverse transcription polymerase chain reaction (RT-PCR)}

Total RNA was isolated from liver and brain tissues by Trizol ${ }^{\circledR}$ reagent (Invitrogen, USA). RNA purity was confirmed by $260 / 280$ ratio. The expression of hepatic MT-I [20] and ATP7B gene [21] along with MT-III [20] and AChE [22] gene expression in brain tissues were determined by semi-quantitative RT-PCR using gene specific primers of MT-I, MT-III, ATP7B, AChE and $\beta$-actin as shown in table 1 with the following conditions: for MT-I: initial 2 min denaturation step at $94{ }^{\circ} \mathrm{C}, 45 \mathrm{sec}$ at $94{ }^{\circ} \mathrm{C}, 1 \mathrm{~min}$ annealing at $58{ }^{\circ} \mathrm{C}, 72{ }^{\circ} \mathrm{C}$ for $1 \mathrm{~min}$ for 35 cycles; for ATP7B: initial 2 min denaturation step at $94{ }^{\circ} \mathrm{C}, 1 \mathrm{~min}$ at $94{ }^{\circ} \mathrm{C}, 1 \mathrm{~min}$ annealing step at $65{ }^{\circ} \mathrm{C}, 1 \mathrm{~min}$ extension step at $72{ }^{\circ} \mathrm{C}$ for 35 cycles and a final 5 min extension at $72{ }^{\circ} \mathrm{C}$; for MT-III: initial 2 min denaturation step at $94{ }^{\circ} \mathrm{C}, 1 \mathrm{~min}$ at $94{ }^{\circ} \mathrm{C}, 30 \mathrm{sec}$ annealing at $52{ }^{\circ} \mathrm{C}, 1 \mathrm{~min}$ at $72{ }^{\circ} \mathrm{C}$ for 30 cycles; for AChE: initial 2 min denaturation step at $94{ }^{\circ} \mathrm{C}, 1 \mathrm{~min}$ at $94^{\circ} \mathrm{C}, 1 \mathrm{~min}$ annealing step at $55^{\circ} \mathrm{C}, 1 \mathrm{~min}$ extension step at $72{ }^{\circ} \mathrm{C}$ for 35 cycles and a final 7 min extension at 72 ${ }^{\circ} \mathrm{C}$; for $\beta$-actin: initial $1 \mathrm{~min}$ denaturation step at $94^{\circ} \mathrm{C}, 1 \mathrm{~min}$ at $94^{\circ} \mathrm{C}, 1 \mathrm{~min}$ annealing step at $58.5^{\circ} \mathrm{C}, 1 \mathrm{~min}$ extension step at 72 ${ }^{\circ} \mathrm{C}$ for 35 cycles and a final 10 min extension at $72{ }^{\circ} \mathrm{C}$. cDNA were prepared by using a RevertAid first strand cDNA synthesis kit (Fermentas) according to manufacturer's protocol. To ensure that equal amounts of reverse transcribed RNA were added to PCR reaction, a parallel amplification of $\beta$-actin mRNA was performed as an internal reference [22]. Gel pictures were taken in Alpha Imager ${ }^{\oplus}$. Signal intensities of the MT-I, ATP7B, MT-III and AChE products were normalized to those of $\beta$-actin products as ratios to produce arbitrary units of relative abundance. Band intensities of the RT-PCR products were quantified by densitometry using Image densitometry software.

\section{Statistical analysis}

All values were expressed as the mean \pm standard error of the mean (SEM) of eight animals in each group. Unpaired Student's $t$ test and Mann-Whitney rank sum test were used for analysis of the data, and values with $\mathrm{p}<0.05$ were considered statistically significant. All the calculations were carried out by the Sigma Stat computer software program. 


\begin{tabular}{|c|c|c|c|}
\hline S.no & Gene & Primer sequence & Product Size (bp) \\
\hline 1 & $\begin{array}{l}\text { Acetylcholinesterase } \\
\text { (AChE) }\end{array}$ & $\begin{array}{l}\text { F-5'-GAC TGC CTT TAT CTT AAT GTG-3' } \\
\text { R-5'-CGG CTG ATG AGA GAT TCA TTG-3' }\end{array}$ & 785 \\
\hline 2 & MT-I & $\begin{array}{l}\text { F-5'-CCCACTGCTCCTGCTCCAC-3' } \\
\text { R-5'-GTCACTTCAGGCACAGCACG-3' }\end{array}$ & 185 \\
\hline 3 & MT-III & $\begin{array}{l}\text { F-5'-ATGCAGCTGCTGCCAGTGAG-3' } \\
\text { R-5'-TGTGCATGGGATTTATTCAC-3' }\end{array}$ & 151 \\
\hline 4 & ATP7B & $\begin{array}{l}\text { F5'CCTCGAGAATTACATCACCGACACTG3' } \\
\text { R5'CCCACCACAGCCAGAACCTTCCTGA3' }\end{array}$ & 332 \\
\hline 5 & $\beta$-actin & $\begin{array}{l}\text { F-5'TAT GCC AAC ACA GTG CTG TCT GG-3' } \\
\text { R-5'-TAC TCC TGC TTC CTG ATC CAC AT-3'. }\end{array}$ & 288 \\
\hline
\end{tabular}

Table 1: Primer sequences of ATP7B, MT-I, MT-III, AChE and $\beta$-actin genes for expression studies using semi-quantitative RTPCR

\section{Results}

\section{Effects of chronic Cu-intoxication on hepatic MT-I and ATP7B gene expression}

Total RNA obtained from liver tissue was used for making cDNA, and then PCR was performed for hepatic MT-I with respective primers as given in Table 1. Hepatic MT-I mRNA fold change in $\mathrm{Cu}$-intoxicated group in comparison to control group are depicted in Figure 1. Semiquantitative study of MT-I mRNA using RT-PCR reactions revealed increased expression of MT-I gene in liver tissues of $\mathrm{Cu}$-intoxicated group as compared to control group (Figure 1). However, there were no significant changes in the expressions levels of hepatic ATP7B gene in $\mathrm{Cu}$-intoxicated group (Data not given).

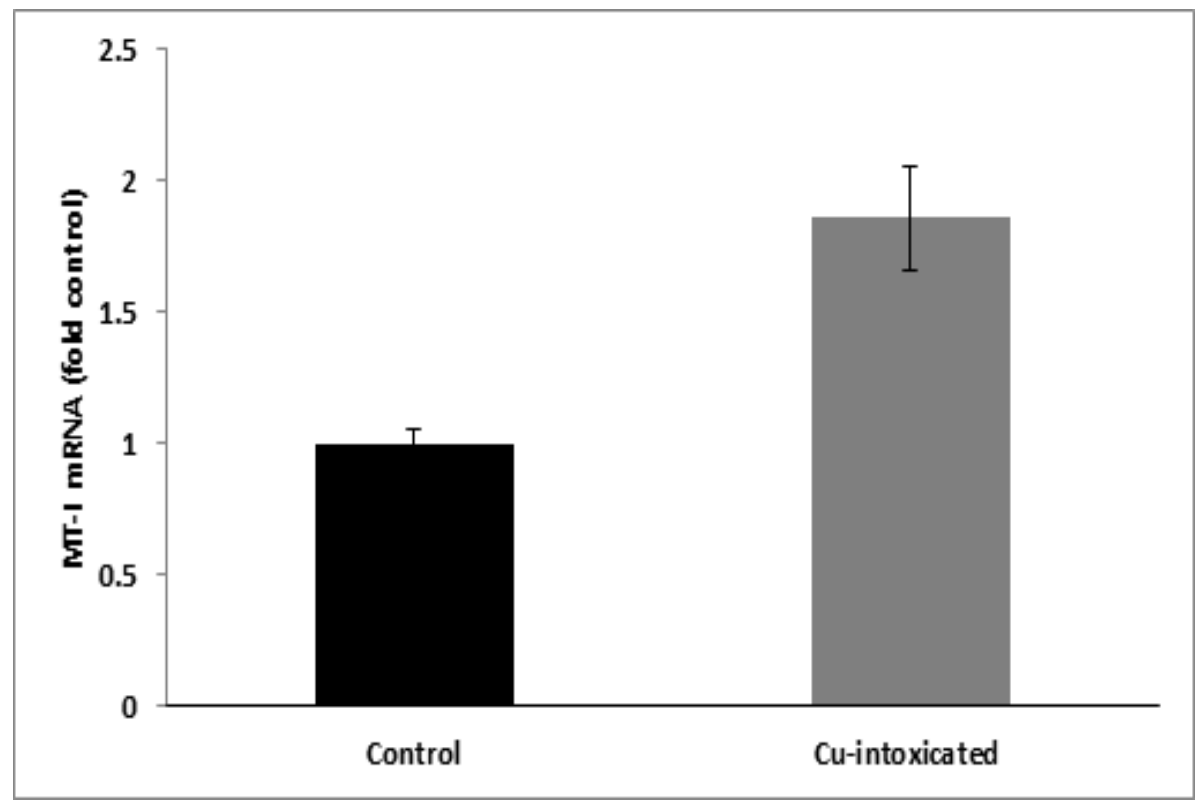

Figure 1: Histogram showing the fold changes in the mRNA expression of MT-I gene in liver tissues Cu-intoxicated group in comparison to control group

\section{Effects of chronic Cu-intoxication on MT-III and AChE gene expression in the brain}

Total RNA extracted from brain tissue was used for making cDNA, and then PCR was performed for AChE and MT-III genes separately with respective primers as given in Table 1. Expressions levels of MT-III, which is a brain specific isoform of MT, in brain tissues of $\mathrm{Cu}$-intoxicated showed non-significant changes compared to control group (Data not given). Similarly, AChE gene mRNA levels in $\mathrm{Cu}$-intoxicated group were comparable with that of control group (Data not given).

\section{Discussion}

The present study documents molecular basis of chronic $\mathrm{Cu}$-intoxication elicited hepatic and neurotoxicity with increased expression of hepatic MT-I gene (Figure 1) in Wistar rat model for non-Wilsonian brain Cu toxicosis [17]. However, there were no changes in the mRNA levels of hepatic ATP7B due to chronic $\mathrm{Cu}$-intoxication. Similarly, no significant effect of Cu-intoxication was found on the MT-III and AChE gene expression in the brain. Results described here point towards the major role of hepatic MT-I in liver $\mathrm{Cu}$ accumulation due to chronic $\mathrm{Cu}$-intoxication corroborated by increased hepatic MT-I gene expression (Figure 1). In addition, we had also shown grade $1 \mathrm{Cu}$-associated protein by Shikata's orcein stain and massive grade $4 \mathrm{Cu}$ deposition by rhodanine stain, respectively in liver sections of $\mathrm{Cu}$-intoxicated animals in the histopathological studies [17]. Liver sections of co- 
trol animals were negatively stained with rhodanine and Shikata's orcein stain. Evans et al. have established that MT is the constituent of the orcein positive material [18]. Thus, implying that MT-I levels are up regulated at both transcription (mRNA) and translation (protein) levels which is substantiated by MT-I RT-PCR (Figure 1) and histopathological studies with orcein stain, respectively. MT-I mRNA levels were also found to be increased in the toxic milk mice [12] which is parallel with our observations. With increased hepatic $\mathrm{Cu}$ loading, MT immunoreactivity was found to be increased periportally with robust panlobular staining for MT in North Ronaldsay sheep, which displays an uncharacteristic sensitivity to dietary Cu. Further, Simpson et al. have also revealed that hepatic Zn concentrations did not increase with increased MT immunoreactivity, thereby, confirming that MT expression was consistent with increase in hepatic $\mathrm{Cu}$ [23], which concurs well with decreased hepatic $\mathrm{Zn}$ content and $\mathrm{Cu}$ associated protein in our previously reported non-Wilsonian rat model of brain $\mathrm{Cu}$ toxicosis [17].

However, there were no significant changes on the MT-III gene expression in the brain of Cu-intoxicated animals in our study. The orcein staining also failed to detect $\mathrm{Cu}$-associated protein in histopathological studies of the brain of $\mathrm{Cu}$-intoxicated animals [17]. Haywood et al. [11] have shown increased immunoreactivity for MT in astrocytes of North Ronaldsay sheep (brain Cu content $343.5 \mu \mathrm{g} \mathrm{Cu} / \mathrm{g}$ ). MTs are ubiquitous proteins characterized by high cysteine and metal content. It is well established that the expression of MT-I proteins is vastly inducible in response to a variety of stimuli, including metals, oxidative agents, inflammation, hormones, cytokines, and stress [24,25]. MTs are induced by toxic metal ions such as cadmium (Cd), mercury and cobalt or essential trace elements such as $\mathrm{Zn}$ and $\mathrm{Cu}$. In addition, MTs also binds to $\mathrm{Cd}, \mathrm{Zn}$ and $\mathrm{Cu}$ [26,27]. At the cellular level, MT is mainly distributed in the cytoplasm and to a lesser extent in the nuclei and lysosomes [28,29]. An overexpression of MT can be caused by $\mathrm{Zn}$ or $\mathrm{Cu}$ exposure and this induction may be due to the role of MTs as antioxidants and electrophilic scavengers [30,31]. Regulation of MT biosynthesis by metals has been considered as a biological device to maintain essential and non-essential free metal ions homeostasis by their chelation. Metal-induced synthesis is mediated through the action of short cisacting DNA sequences known as metal responsive elements (MREs), which are present in the promoter region of all mammalian MT genes [32,33]. Nevertheless, the regulation of MT-III gene expression is poorly known [9].

The mechanisms for $\mathrm{Cu}$ accumulation due to chronic $\mathrm{Cu}$-intoxication seems apparently different from those observed in WD as evident by no changes in the mRNA levels of the hepatic ATP7B gene, and increased serum ceruloplasmin and serum Cu levels in $\mathrm{Cu}$-intoxicated animals [17]. Copper Metabolism gene MURR1 containing Domain 1 (COMMD1), is a recently identified gene which has been hypothesized as essential for $\mathrm{Cu}$ excretion at the biliary pole of hepatocytes, acting downstream ATP7B. Its mutation is responsible for Bedlington terrier copper toxicosis (BTCT), an animal model of WD [34]. ATP7B is found primarily localized in hepatocytes and it is vital for the regulation of $\mathrm{Cu}$ homeostasis in mammals [35]. When extracellular Cu concentration is below $1 \mu \mathrm{mol} / \mathrm{L}$, hepatic ATP7B is located in the trans-Golgi network (TGN) and delivers Cu ions to vital cuproenzymes; however, under augmented $\mathrm{Cu}$ stress ATP7B sense the increased $\mathrm{Cu}$ levels and translocate to the biliary canaliculi and to vesicular structures to excrete the surplus of intracellular $\mathrm{Cu}$ [36-38]. The function of ATP7B in tissues other than liver is unclear [37].

Non-Wilsonian forms of liver $\mathrm{Cu}$ toxicosis in humans that often occur early in childhood include endemic Tyrolean infantile cirrhosis (ETIC) [39], Indian childhood cirrhosis (ICC) [40], and ICT [41]. Genetic defects in these rare diseases of Cu toxicosis have not been identified until now, but high dietary $\mathrm{Cu}$ ingestion or consumption of inorganic $\mathrm{Cu}$ in drinking water and supplements [42], and consanguinity are reported to be involved in the pathogenesis of these Cu toxicosis diseases, which clearly indicates towards genetic cause altered by environmental and dietary/drinking water factors [34].

AChE hydrolyses cholinergic neurotransmitter, acetylcholine, to acetate and choline. Acetylcholine transmits the nerve impulse from one neuron to another i.e. from the presynaptic terminus, through the synaptic cleft to the specific receptors on postsynaptic terminus, so that propagation of the signal can take place. Acetylcholine is involved in memory, learning, control of motor tone, locomotion, cortical activation, attention, pain and control of autonomic functions [43]. The cholinergic system is involved in synaptic plasticity; memory and learning with deficits in it are reported to be robustly related to neurodegenerative diseases [44]. In our study, significant decrease in the serum AChE activity [17] along with non-significant changes on the AChE gene expression were documented in $\mathrm{Cu}$-intoxicated animals. In concurrence, $\mathrm{Cu}$ toxicity has been shown to induce neurobehavioral effects probably by affecting the "cholinergic anti-inflammatory pathway" [45]. Nevertheless, molecular mechanism for decrease in AChE activity due to chronic Cu-intoxication is not known. Leiva et al. [46] have suggested a possible relationship between $\mathrm{Cu}$ and cholinergic receptors. Actually, Farrar and Hoss [47] have shown that brain areas with a high concentration of $\mathrm{Cu}$, such as hippocampus, cerebral cortex, forebrain and striatum, overlap sites of cholinergic innervation [46]. Cholinergic agonists can facilitate memory, whereas cholinergic antagonists can impair memory [15,48]. From the above quoted references, we can say that $\mathrm{Cu}$ toxicity can diminish the AChE enzyme activity without altering the AChE gene expression, and the observed impaired AChE activity could interfere with cholinergic neurotransmission, affecting learning, memory, cognition and motor functions of $\mathrm{Cu}$-intoxicated animals.

\section{Conclusion}

In conclusion, in the present study it was found that hepatic MT-I gene expression increased significantly but hepatic ATP7B gene, and brain MT-III and AChE gene expression remained unaltered due to chronic Cu-intoxication in Wistar rat model for nonWilsonian brain $\mathrm{Cu}$ toxicosis. However, more studies addressing the molecular mechanisms underlying neuronal apoptosis due 
to buildup of $\mathrm{Cu}$ in different regions of brain together with interaction between different cells of brain parenchyma (neurons, astrocytes, microglia, oligodendroglia and endothelial cells) in the CNS Cu homeostasis are warranted to elucidate molecular mechanisms of chronic $\mathrm{Cu}$ toxicity associated cognitive deficits and neurodegeneration.

\section{Acknowledgement}

The authors acknowledge the financial assistance provided by Indian Council of Medical Research (I.C.M.R., New Delhi) as JRF to Mr. Amit Pal [3/1/3/JRF-2009/MPD-13 (11279)]. Authors acknowledge the support of Mr. Rakesh Mohindra for statistics.

\section{References}

1. Que EL, Domaille DW, Chang CJ (2008) Metals in neurobiology: probing their chemistry and biology with molecular imaging. Chem Rev 108: 1517-49.

2. Tapiero H, Townsend DM, Tew KD (2003) Trace elements in human physiology and pathology. Copper. Biomed Pharmacother 57: 386-98.

3. Prohaska JR, Wells WW (1974) Copper deficiency in the developing rat brain: a possible model for Menkes' steely-hair disease. J Neurochem 23: 91-8.

4. Lutsenko S, Bhattacharjee A, Hubbard AL (2010) Copper handling machinery of the brain. Metallomics 2: 596-608.

5. Ozcelik D, Uzun H (2009) Copper intoxication; antioxidant defenses and oxidative damage in rat brain. Biol Trace Elem Res 127: 45-52.

6. Sturniolo GC, Mestriner C, Irato P, Albergoni V, Longo G, et al. (1999) Zinc therapy increases duodenal concentrations of metallothionein and iron in Wilson's disease patients. Am J Gastroenterol 94: 334-8.

7. Palmiter RD, Findley SD, Whitmore TE, Durnam DM (1992) MT-III, a brain-specific member of the metallothionein gene family. Proc Natl Acad Sci USA 89: 6333-7.

8. Quaife CJ, Findley SD, Erickson JC, Froelick GJ, Kelly EJ, et al. (1994) Induction of a new metallothionein isoform (MT-IV) occurs during differentiation of stratified squamous epithelia. Biochemistry 33: 7250-9.

9. West AK, Hidalgo J, Eddins D, Levin ED, Aschner M (2008) Metallothionein in the central nervous system: Roles in protection, regeneration and cognition. Neurotoxicology 29: 489-503.

10. Aschner M, Syversen T, Souza DO, Rocha JB (2006) Metallothioneins: mercury species-specific induction and their potential role in attenuating neurotoxicity. Exp Biol Med (Maywood) 231: 1468-73.

11. Haywood S, Paris J, Ryvar R, Botteron C (2008) Brain copper elevation and neurological changes in north ronaldsay sheep: a model for neurodegenerative disease? J Comp Pathol 139: 252-5.

12. Mercer JF, Paynter JA, Grimes A (1994) The toxic milk mouse does have elevated hepatic metallothionein mRNA. Biochem J 304: 317-8.

13. Llanos RM, Mercer JF (2002) The molecular basis of copper homeostasis copper-related disorders. DNA Cell Biol 21: 259-70.

14. Rossi L, Squitti R, Calabrese L, Rotilio G, Rossini PM (2007) Alteration of peripheral markers of copper homeostasis in Alzheimer's disease patients: implications in aetiology and therapy. J Nutr Health Aging 11: 408-17.

15. Overstreet DH (1984) Behavioral plasticity and the cholinergic system. Prog Neuropsychopharmacol Biol Psychiatry 8: 133-51.

16. Frasco MF, Fournier D, Carvalho F, Guilhermino L (2005) Do metals inhibit acetylcholinesterase (AChE)? Implementation of assay conditions for the use of AChE activity as a biomarker of metal toxicity. Biomarkers 10: 360-75.

17. Pal A, Badyal RK, Vasishta RK, Attri SV, Thapa BR, et al. (2013) Biochemical, Histological, and Memory Impairment Effects of Chronic Copper Toxicity: A Model for Non-Wilsonian Brain Copper Toxicosis in Wistar Rat. Biol Trace Elem Res 153: 257-68.

18. Evans J, Newman SP, Sherlock S (1980) Observations on copper associated protein in childhood liver disease. Gut 21: 970-6.

19. Narasaki M (1980) Laboratory and histological similarities between Wilson's disease and rats with copper toxicity. Acta Med Okayama 34: 81-90.

20. Mocchegiani E, Giacconi R, Fattoretti P, Casoli T, Cipriano C, et al. (2004) Metallothionein isoforms (I+II and III) and interleukin-6 in the hippocampus of old rats: may their concomitant increments lead to neurodegeneration? Brain Res Bull 63: 133-42.

21. Fedotova Y, Babich P, Platonova N, Klotchenko S, Tsymbalenko N, et al. (2006) Expression of copper-transporting genes in the rat brain in experimental dementia of Alzheimer type. Doklady Biological Sciences 409: 281-4.

22. Jamal M, Ameno K, Ameno S, Morishita J, Wang W, et al. (2007) Changes in cholinergic function in the frontal cortex and hippocampus of rat exposed to ethanol and acetaldehyde. Neuroscience 144: 232-8.

23. Simpson DM, Mobasheri A, Haywood S, Beynon RJ (2006) A proteomics study of the response of North Ronaldsay sheep to copper challenge. BMC Vet Res 2: 36 .

24. Bremner I (1987) Nutritional and physiological significance of metallothionein. Experientia Suppl 52: 81-107.

25. Sato M, Bremner I (1993) Oxygen free radicals and metallothionein. Free Radic Biol Med 14: 325-7.

26. Henry RB, Liu J, Choudhuri S, Klaassen CD (1994) Species variation in hepatic metallothionein. Toxicol Lett 74: 23-33.

27. Tapiero H, Tew KD (2003) Trace elements in human physiology and pathology: zinc and metallothioneins. Biomed Pharmacother 57: 399-411.

28. Panemangalore M, Banerjee D, Onosaka S, Cherian MG (1983) Changes in the intracellular accumulation and distribution of metallothionein in rat liver and kidney during postnatal development. Dev Biol 97: 95-102.

29. Nartey NO, Banerjee D, Cherian MG (1987) Immunohistochemical localization of metallothionein in cell nucleus and cytoplasm of fetal human liver and kidney and its changes during development. Pathology 19: 233-8.

30. Bremner I (1987) Involvement of metallothionein in the hepatic metabolism of copper. J Nutr 117: 19-29.

31. Moffatt P, Plaa GL, Denizeau F (1996) Rat hepatocytes with elevated metallothionein expression are resistant to N-methyl-N'-nitro-N-nitrosoguanidine cytotoxicity. Toxicol Appl Pharmacol 136: 200-7.

32. Karin M, Haslinger A, Holtgreve H, Richards RI, Krauter P, et al. (1984) Characterization of DNA sequences through which cadmium and glucocorticoid hormones induce human metallothionein-IIA gene. Nature 308: 513-9.

33. Radtke F, Heuchel R, Georgiev O, Hergersberg M, Gariglio M, et al. (1993) Cloned transcription factor MTF-1 activates the mouse metallothionein I promoter. EMBO J 12: 1355-62. 
34. Fieten H, Leegwater PA, Watson AL, Rothuizen J (2012) Canine models of copper toxicosis for understanding mammalian copper metabolism. Mamm Genome 23: 62-75.

35. Lutsenko S, Barnes NL, Bartee MY, Dmitriev OY (2007) Function and regulation of human copper-transporting ATPases. Physiol Rev 87: 1011 -46.

36. La Fontaine S, Mercer JF (2007) Trafficking of the copper-ATPases, ATP7A and ATP7B: role in copper homeostasis. Arch Biochem Biophys 463: 149-67.

37. Crisponi G, Nurchi VM, Fanni D, Gerosa C, Nemolato S, et al. (2010) Copper-related diseases: From chemistry to molecular pathology. Coordination Chemistry Reviews 254: 876-89.

38. Roelofsen H, Wolters H, Van Luyn MJ, Miura N, Kuipers F, et al. (2000) Copper-induced apical trafficking of ATP7B in polarized hepatoma cells provides a mechanism for biliary copper excretion. Gastroenterology 119: 782-93.

39. Muller T, Feichtinger H, Berger H, Muller W (1996) Endemic Tyrolean infantile cirrhosis: an ecogenetic disorder. Lancet 347: 877-80.

40. Tanner MS (1998) Role of copper in Indian childhood cirrhosis. Am J Clin Nutr 67: 1074S-81.

41. Scheinberg IH, Sternlieb I (1996) Wilson disease and idiopathic copper toxicosis. Am J Clin Nutr 63: 842S-5.

42. Brewer GJ, Kanzer SH, Zimmerman EA, Celmins DF, Heckman SM, et al. (2010) Copper and ceruloplasmin abnormalities in Alzheimer's disease. Am J Alzheimers Dis Other Demen 25: 490-7.

43. Herlenius E, Lagercrantz H (2004) Development of neurotransmitter systems during critical periods. Exp Neurol 190: S8-21.

44. Oda Y (1999) Choline acetyltransferase: the structure, distribution and pathologic changes in the central nervous system. Pathol Int 49: 921-37.

45. Halatek T, Lutz P, Krajnow A, Stetkiewicz J, Domeradzka K, et al. (2011) Assessment of neurobehavioral and biochemical effects in rats exposed to copper smelter dusts. J Environ Sci Health A Tox Hazard Subst Environ Eng 46: 230-41.

46. Leiva J, Palestini M, Infante C, Goldschmidt A, Motles E (2009) Copper suppresses hippocampus LTP in the rat, but does not alter learning or memory in the morris water maze. Brain Res 1256: 69-75.

47. Farrar JR, Hoss W (1984) Effects of copper on the binding of agonists and antagonists to muscarinic receptors in rat brain. Biochem Pharmacol 33: 2849-56. 48. Drever BD, Riedel G, Platt B (2011) The cholinergic system and hippocampal plasticity. Behav Brain Res 221: 505-14.

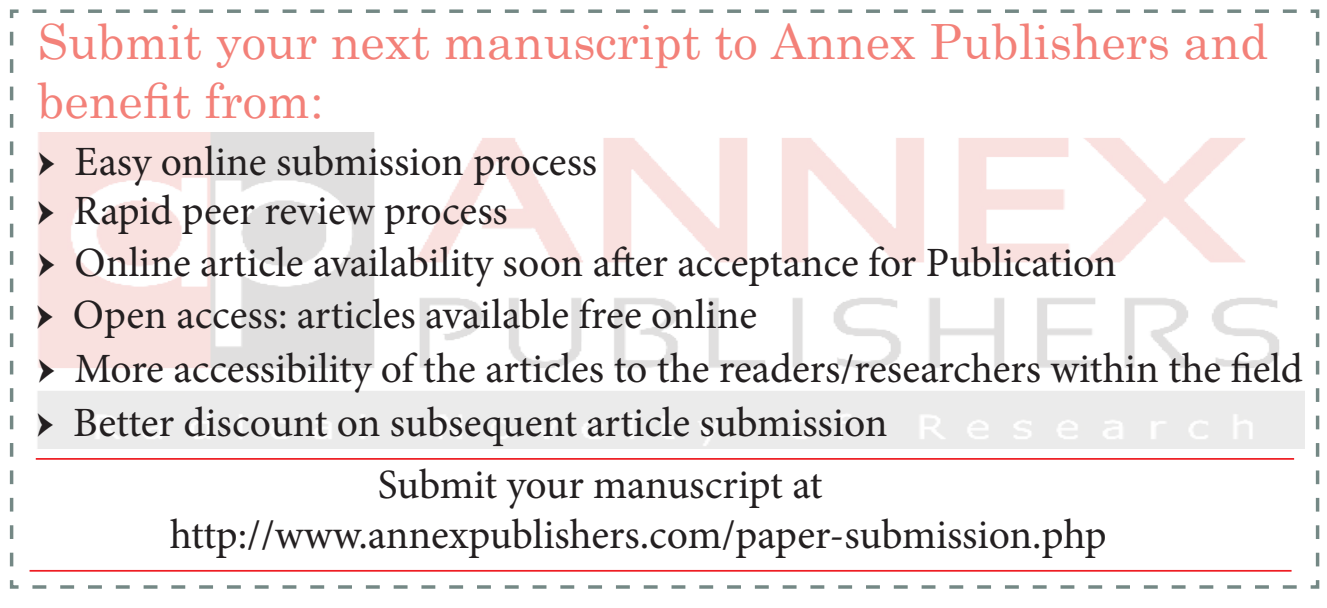

